\title{
How individual experiential backgrounds are related to the development of employability among university students
}

\author{
Andreas Eimer ${ }^{1}$ and Carla Bohndick ${ }^{2}$ \\ Corresponding author: Andreas Eimer (andreas.eimer@uni-muenster.de ) \\ ${ }^{1}$ University of Muenster, https://orcid.org/0000-0002-5136-2576 \\ ${ }^{2}$ University of Hamburg, https://orcid.org/0000-0003-1079-8098
}

\begin{abstract}
University students have different backgrounds and varied experiences. This diversity has frequently been examined with regard to performance in Higher Education. However, much less attention has been paid to its significance concerning employability. The investigation of this potential relationship is the focus of this study. In this research, 429 students at a German university were assessed on the strength of their employability, which here is defined as a multi-factorial construct. The Career Resources Questionnaire (CRQ) was used (Hirschi et al., 2019) which is a comprehensive instrument that analyses the self-assessed strength of twelve essential career resources amongst respondents. The results were then related to several individual preconditions: existing or non-existing commitment to voluntary work, sporting activity or sporting inactivity and being a first-generation student (FGS) or a continuinggeneration student (CGS). These characteristics were chosen, because they are commonly represented in the student population. In addition, some socio-economic implications are discussed. Significant differences were found between the participant groups. Some results correspond with the findings of existing studies, others lead to new explanatory approaches. Based on the overall findings, recommendations for career counselling as well as for seminars in career orientation are given. For example, students' experiences outside the university environment can be used in career counselling to strengthen perceived employability or a supportive approach to first-generation students can lead to the development of careerrelated strengths.
\end{abstract}

\section{Introduction}

In many countries of the world, employability is high on the economic agenda. With rising student numbers (UNESCO International Institute for Education Planning [IIEP], 2017) a career in academia is only one option for graduates. Most students regard a Higher Education degree as a preparation for their professional life. High student numbers combined with a diverse student population, a varied and dynamic labour market, and the expectation of students to be well prepared for a professional life puts the focus on employability (OECD, 2017). Interestingly, different countries see the need to strengthen students' employability from different angles. For example, it is a competitive aspect between US-American Higher Education institutions, while in the UK we see a discussion about

Eimer, A., \& Bohndick, C. (2021). How individual experiential backgrounds are related to the development of employability among university students. Journal of Teaching and Learning for Graduate Employability, 12(2), 114-130. 
graduate skills often sparked by the government (Department for Business Innovation \& Skills, 2016) and driven by graduate employment league tables. In the Middle East and Northern Africa (MENARegion) the strong employability of graduates is meant to decrease the high unemployment rates and to help the economy grow. In this way, governments in the region aim to stabilize the social structures after the revolutionary movements of the Arab Spring in the early 2010s (Murata, 2014). Moreover, in Australia and Singapore, for example, graduates' success in the labour market is a sales argument to advertise international degree programs to the world (e.g. International Education Association Australia [IEAA], 2019; NUSNews, 2016). In Germany, employability is one of a number of defined outcomes from studying at a Higher Education institution and is anchored in a number of official declarations and regulations (Eimer et al., 2019).

Reflecting on the related literature, Moreau \& Leathwood (2006) focus on the relevance of students' individual preconditions for their (prospective) employability. It is relevant to know more about these preconditions: If students differ in these aspects, support services - for example careers services - might need to adapt to these heterogeneous circumstances. Counsellors in individual counselling sessions and teachers in employability workshops can thus better address these differences and cater for the individual developmental needs and potentials of the students.

This means, it is not enough to merely identify heterogeneity, it is also important to develop solutions for how governments and Higher Education institutions can support students from different backgrounds in achieving not only their study goals but their employability too. This study aims to provide some practical guidance in this respect.

\section{Context of this study}

\section{Employability as a multi-factorial construct}

Employability can be described as a multi-factorial construct in which various influencing factors play a role. In this vein, employability can be understood as an umbrella term for the existence of certain qualities, which lead to objective and subjective career success ( $\mathrm{Ng}$ et al., 2005). This means that people who score highly in the employability related constructs have a higher probability of achieving objective and/or subjective career success than people who score lower in these constructs. Objective career success is usually characterized by criteria such as salary or promotions, whereas subjective career success is related to individual perceptions of one's own career such as job or career satisfaction. There are several studies which focus on the potential correlation between single factors and objective and/or subjective career success, e.g. the influence of selfefficacy (Abele-Brehm \& Spurk, 2009), personality traits (Sutin et al., 2009), self-esteem (KammeyerMueller, Judge, \& Piccolo, 2008), networking (Wolff \& Moser, 2009).

Hirschi (2012) gives a comprehensive overview of the scientific literature on factors strengthening employability, also applying the construct of objective and subjective career success. Hirschi's approach offers a particular advantage as he combines a large number of factors identified through prior research, which correlate to objective and subjective career success, into a single coherent model. The Career Resources Model focuses on factors that can individually be developed and is less aimed at relatively stable traits or characteristics (such as personality traits or gender) and in addition these factors as a whole show a stronger correlation with indicators of subjective rather than objective career success (Hirschi et al., 2019). This model and the questionnaire based on the model was applied in this study (cf. 3.3).

\section{Focus of this study}

This research focused on the influence of volunteering, participating in sports and being a firstgeneration student on the development of employability. Volunteering is defined here as working or 
providing services free of charge, including for example helping other people and improving social situations. Participating in sport is defined here as regularly taking part in sporting activities - either individually or through a sports club, but not being a professional athlete. In this project, being a first-generation student means being the first member of the family seeking an academic degree. These three individual preconditions of employability were selected for several reasons.

First, the three aspects considered meant the inclusion of a large group of students. A survey conducted in 2020 in the UK demonstrated significant numbers of young people engaged in voluntary work, e.g. $38.8 \%$ of the 16- to 24-year olds in England in 2019/20 (Department for Digital, Culture, Media and Sport [UK], 2020). Being active in sport is also common in the student population, for example documented by the large sports programs almost all universities offer. Finally, we see a high number of first-generation students, in the academic year 2015-16 totalling 56 $\%$ of all undergraduate college students in the US (RTI International, 2019).

In addition, Brunton (2017) found that only one out of the eight examined universities integrated sport into their university strategy with the explicit intention to achieve positive effects beyond physical fitness. They advocate for more research into the outcomes of sports on other parameters such as recruitment, retention, graduate employability, mental health, and student satisfaction. In general, there has been little research on the relationship between participating in sport and graduate employability, which was a further reason to include this aspect in this study.

If involvement in sport and voluntary work enhances the employability of students, this could benefit all students. However, it is known that the individual strength of employability also depends on socio-economic aspects (Lehmann, 2019). Family social networks facilitate access to volunteering opportunities and one's own financial means often are needed to work as an unpaid volunteer (Lehmann, 2019). These factors may mean first-generation students are disadvantaged compared to continuing-generation students. This will be explored further in the section 'Practical implications'.

\section{Individual preconditions}

This study is based on self-assessed employability and thus sheds light on an individual's perspective on one's own sense of being prepared for the world of work, focusing on an understanding of employability that centres on the development of a holistic 'graduate identity' (Hinchliffe \& Jolly, 2011). This approach differs significantly from a definition of employability based on fixed skills, which places human capital in the form of formally learned skills at the centre. On the one hand, the authors of this paper share the many criticisms of an approach only focusing on human capital (Hinchliffe \& Jolly, 2011). Lists of skills do not take into account a number of other factors e.g. biographical differences and prerequisites as well as other forms of capital beyond human capital (e.g. social capital). At the same time, it is known that first-generation students, in particular, focus on formal qualifications acquired during their studies and neglect other elements that are important for professional success (e.g. networking) (Lehmann, 2019). Adopting a tick box approach to skills development could produce skewed employability profiles and indirectly reinforce respondents' assumptions of the sole importance of human capital. The approach advocated here, therefore, is consciously based on subjective perception and covers aspects that go beyond formal qualifications and skills.

\section{Voluntary work}

In general, research demonstrates that acquiring working experience has a positive impact on the development of students' employability and specifically on a number of personal attributes such as confidence and self-efficacy (Millard, 2020; Muldoon, 2009). In addition, gaining this experience adds to the social capital of students (Goodman \& Tredway, 2016). This study adopted a particular focus on volunteering due to the likely intrinsic motivations for individuals to engage in this activity, taking the source of motivation well away from a pure monetary value. For example, students may

Eimer, A., \& Bohndick, C. (2021). How individual experiential backgrounds are related to the development of employability among university students. Journal of Teaching and Learning for Graduate Employability, 12(2), 114-130. 
be motivated by their own personal values, interests and career perspectives in the field and these aspects are addressed in the Career Resources Questionnaire (CRQ) applied in this study.

A number of studies, which are relevant for this research, have described the different effects volunteering can have on students' employability and made reference to strengthening confidence (Astin, Say, \& Avalos, 1999; Barton, Bates, \& O'Donovan, 2017; Millard, 2020) and building social capital, such as networks (Bourner \& Millican, 2011). Other studies describe the development of hard and soft skills, knowledge and occupational expertise (Barton et al., 2017; Jackson, 2012; SoutoOtero, Ulicna, Schaepkens, \& Bognar, 2012). Bourner and Millican (2011) found evidence that volunteering helps students explore their strengths and talents, which can lead to greater clarity about future career plans.

You (2020) found a positive relationship between doing community service and career motivation. Finally, a Flemish study by Hustinx et al. (2005) shows that many students give up volunteering when they enter university, prioritising their time to their study obligations.

In summary, from the literature it may be suggested that students who engage in voluntary work might score higher in the CRQ-resources which indicate occupational expertise, soft skills, confidence, clarity, and networking in comparison with students who are not active in volunteering. Conversely, it could be possible that students who are engaged in voluntary work during their studies might do so at the expense of their university engagement.

\section{Sport}

There is very little research on the effect sport might have on student employability (Allen et al., 2013). This fact is remarkable in the light of governmental recommendations, for example in the UK and on an EU level, to consider the effects of sport in a broader context. Official reports advocate for more research into the effects of sport not only on health status, but also on other aspects, such as employability etc. (HM Government, 2015; The Council of the European Union, 2014). Sportsociologist Jay Coakley (2015) takes a more sceptical stance towards the effect of sport on different individual qualities. He sees the Great Sport Myth (GSM) as a reason that governments invest large sums of public money in sports infrastructure based on the assumption that sport has positive effects on academic motivation and personal development.

In a comprehensive secondary analysis (Allen et al., 2013), it was shown that graduates who are active in sports earn a higher average salary and score more highly in a number of work relevant soft skills than graduates who are inactive in sports. Perry (2014) describes sport as supporting mental toughness. It is suggested that these factors which enhance clarity and confidence, can lead to higher employability.

In contrast, other studies point to the negative effects sport can have on students' study behaviour. A US study by Dwyer and Gellock (2018) describes the potentially high amount of time some students can spend on sporting activities, which can then conflict with study activities (e.g. internships). Other studies (Martha, Grélot, \& Peretti-Watel, 2009) refer to other negative impacts including the connection between sports activities of students and increased alcohol consumption and the possible negative impact on these students' studies.

Overall, the literature provides some insights into how students who participate in sports might score higher in soft skills, confidence, and clarity, but lower in engagement in their studies than students not doing sports and yet still going on to achieve higher salaries.

\section{First Generation}

There are findings that draw attention to the socio-economic differences between FGS and CGS: First-generation graduates earn less than continuing-generation graduates ten years after 
completing college, this being due to continuing-generation students being more likely to work with employers associated with higher pay (Manzoni \& Streib, 2019). A US qualitative exploratory study (Tate et al., 2015) found that first-generation students possess a smaller career/professional network compared to continuing-generation students. Although interestingly, the first group described themselves as more motivated, self-reliant, and adaptable.

The results and level of self-efficacy of being first in family to engage in Higher Education are inconsistent. In a US study (Gervais, 2014), first-generation students showed less self-efficacy, however this group did not differ from CGS in their levels of motivation. Whilst Knutson (2011) found no significant differences of academic self-efficacy between first-generation and continuinggeneration students. Further research from the US (Gibbons \& Borders, 2010) showed a group of prospective first-generation college students with lower self-efficacy, higher negative outcome expectations, and more perceived barriers than school students from families with a typically stronger academic background.

More than 2,000 undergraduate students from a US university participated in a study on career aspirations (Raque-Bogdan \& Lucas, 2016). Results showed no differences between FGS and CGS on college self-efficacy, college outcome expectations, and career expectations. Interestingly, however, the authors found in first-generation students an individualistic mindset in that they alone are responsible for their fate (Raque-Bogdan \& Lucas, 2016, p. 258), which makes a high level of involvement very likely. At the same time, this individualistic stance could make first-generation students hesitant to make use of institutional support, which is one resource relevant in this research. Jenkins et al. (2013) found that first-generation students reported lower levels of social support from family and friends than continuing-generation students.

In summary, this research presents arguments that FGS may have smaller career networks, weaker social support and eventually a lower income than CGS. At the same time, there are suggestions that FGS show high levels of self-responsibility and are as motivated as CGS. The results around the development of self-efficacy are inconsistent. It is acknowledged that these impacts linked to FSG observed in the literature need to be simplified in our hypotheses in order to formulate testable assumptions.

\section{Methodology}

\section{Hypotheses}

This study aimed to investigate the effect of volunteering, participating in sport and being a first generation higher education student on employability. Based on the research literature presented above, the hypothesis is that the following differences may be observed between the respective comparison groups as shown in Table 1.

Table 1: Hypotheses

\begin{tabular}{llll}
\hline CRQ-Dimension & Volunteers & Sports participants & First Generation \\
\hline Occupational Expertise & + & n/a & n/a \\
Job Market Knowledge & n/a & n/a & n/a \\
Soft Skills & + & + & n/a \\
Involvement & - & - & + \\
Confidence & + & + & n/a \\
Clarity & + & + & n/a
\end{tabular}

Eimer, A., \& Bohndick, C. (2021). How individual experiential backgrounds are related to the development of employability among 


\begin{tabular}{llll} 
Institutional Support & $\mathrm{n} / \mathrm{a}$ & $\mathrm{n} / \mathrm{a}$ & - \\
Study Challenge & $\mathrm{n} / \mathrm{a}$ & $\mathrm{n} / \mathrm{a}$ & $\mathrm{n} / \mathrm{a}$ \\
Social Support & $\mathrm{n} / \mathrm{a}$ & $\mathrm{n} / \mathrm{a}$ & - \\
Networking & + & $\mathrm{n} / \mathrm{a}$ & - \\
Career Information. Gathering & $\mathrm{n} / \mathrm{a}$ & $\mathrm{n} / \mathrm{a}$ & $\mathrm{n} / \mathrm{a}$ \\
Continuous Learning & $\mathrm{n} / \mathrm{a}$ & $\mathrm{n} / \mathrm{a}$ & $\mathrm{n} / \mathrm{a}$ \\
\hline
\end{tabular}

Note. + scoring significantly higher in employability than comparison group, - scoring significantly lower in employability than comparison group, $\mathrm{n} / \mathrm{a}$ : not assigned, i.e. no hypothesis formulated on this aspect

\section{Research design}

This quantitative field study was conducted from June to July 2020 with 26 university teachers from various disciplines being asked to pass on a web link to their students requesting they complete an online questionnaire. 429 students completed the questionnaire.

A random sampling methodology was adopted in this study.

\section{Research participants}

The sample consisted of current full-time students from a traditional research university in Germany. The participants were studying for various qualifications: Bachelor (38.7\%), Master (24.7\%), PhD (3.0\%) and the German degree in Law and teachers' training, the Staatsexamen (32.6\%), which is equivalent to a Master's degree. The participants were asked by their professors to complete the questionnaire anonymously. The participants were informed that the results of the survey would be used for a research project on the employability of students. Participation in the survey was anonymous and completely voluntary. The participants were informed about their rights. An ethics approval was not required.

In total, 429 persons completed the online questionnaire. $72 \%$ of the respondents categorized themselves as female, $26.6 \%$ as male, and $0.7 \%$ as diverse. The age range was 18 to 55 years, the mean being $M=22.8$ years, $S D=3.83 .92 .8 \%$ of all respondents ranged between the age of 18 and 27 , the largest group being the 23 -years olds $(16.1 \%)$. The distribution between the study programs is as follows: $33.6 \%$ natural sciences, $25.4 \%$ law, $22.9 \%$ social sciences, $15.4 \%$ arts, 9.1 medicine, and $3.5 \%$ business. Students enrolled in more than one study program explain the percentage of over $100 \%$.

\section{Measuring instrument}

We used the Career Resources Questionnaire (CRQ) for students in the validated German version (Hirschi et al., 2019). The CRQ asks for the participants' self-assessment on a five-tiered scale: disagree strongly (1), disagree a little (2), neither agree nor disagree $(3$,$) agree a little (4), agree$ strongly (5). Each dimension was surveyed with at least three items, in some cases four items.

This CRQ comprises 12 resources for students (13 for employees), which are grouped into four categories:

1) Knowledge and Skills with the resources occupational expertise, job market knowledge, and soft skills;

2) Motivation with the resources involvement, confidence, and clarity;

3) Environment with the resources institutional support, study challenge, and social support, and 
4) Activities with the resources networking, career information gathering, and continuous learning.

The 12 resources of the Career Resources Model are explained as follows:

- Occupational expertise: job-specific knowledge and skills;

- Job market knowledge: general knowledge about the labour market and its developments;

- Soft skills: skills and competences applicable to a wide range of occupations;

- Involvement: emotional attachment to one's studies;

- Confidence: belief that one's own career can be successfully managed;

- Clarity: clarity and self-determination of career objectives;

- Institutional support: support of career development by university/college;

- Study challenge: opportunity to apply and develop personally important skills;

- Social support: support for career development from other people;

- Networking: extent to which social contacts are established, maintained and used to develop one's own career;

- Career information gathering: the extent to which one collects information on career opportunities;

- Continuous learning: the extent to which one continuously expands and updates workspecific knowledge and skills (cf. Hirschi et al., 2018, 2019).

The CRQ for students comprises 38 items. The internal consistencies (Cronbach's Alpha) ranged from .70 to .92. The descriptors for the CRQ can be seen in Table 2. The CRQ was followed by additional questions formulated by the authors to identify first-generation students, students who volunteered and students who participated in sports. Other aspects were also included, for example the discussion tone within the family on the topic of work, which, however, are not considered further in this paper. 
Table 2: Measurement Instruments, CRQ-Sample Items, and Intercorrelations

\begin{tabular}{|c|c|c|c|c|c|c|c|c|c|c|c|c|c|c|c|}
\hline CRQ-Dimension & Sample item & $k$ & $M(S D)$ & $\alpha$ & 1 & 2 & 3 & 4 & 5 & 6 & 7 & 8 & 9 & 10 & 11 \\
\hline 1 Occup. Expertise & $\begin{array}{l}\text { 'I possess profound knowledge in my } \\
\text { desired occupation.' }\end{array}$ & 3 & $3.18(0.78)$ & .74 & & & & & & & & & & & \\
\hline 2 Job Market Knowl. & $\begin{array}{l}\text { 'I have a good knowledge of the job } \\
\text { market.' }\end{array}$ & 3 & $2.42(1.00)$ & .91 & .39 & & & & & & & & & & \\
\hline 3 Soft Skills & $\begin{array}{l}\text { 'I have many skills that I could use in a } \\
\text { range of different occupations.' }\end{array}$ & 3 & $3.82(0.81)$ & .87 & .42 & .26 & & & & & & & & & \\
\hline 4 Involvement & $\begin{array}{l}\text { 'I feel strongly attached to my } \\
\text { studies.' }\end{array}$ & 3 & $3.96(0.81)$ & .76 & .27 & .10 & .07 & & & & & & & & \\
\hline 5 Confidence & $\begin{array}{l}\text { 'I am capable of successfully managing } \\
\text { my career.' }\end{array}$ & 4 & $3.68(0.77)$ & .84 & .59 & .33 & .44 & .32 & & & & & & & \\
\hline 6 Clarity & $\begin{array}{l}\text { 'I have clear career goals that reflect } \\
\text { my personal interests and values.' }\end{array}$ & 3 & $3.52(1.10)$ & .92 & .43 & .38 & .21 & .26 & .49 & & & & & & \\
\hline 7 Institut. Support & $\begin{array}{l}\text { 'My university/college actively } \\
\text { supports my career development.' }\end{array}$ & 3 & $2.94(0.94)$ & .87 & .30 & .18 & .15 & .37 & .38 & .20 & & & & & \\
\hline 8 Study Challenge & $\begin{array}{l}\text { 'My current studies fully challenge my } \\
\text { skills.' }\end{array}$ & 3 & $2.94(0.94)$ & .87 & .30 & .13 & .18 & .57 & .36 & .23 & .46 & & & & \\
\hline 9 Social Support & $\begin{array}{l}\text { 'I know many people who support me } \\
\text { in my career development'. }\end{array}$ & 4 & $3.50(0.83)$ & .73 & .35 & .22 & .24 & .30 & .44 & .26 & .42 & .35 & & & \\
\hline 10 Networking & $\begin{array}{l}\text { 'I frequently utilize contacts with } \\
\text { other people to advance my career.' }\end{array}$ & 3 & $2.80(1.00)$ & .85 & .42 & .46 & .29 & .21 & .37 & .32 & .24 & .20 & .45 & & \\
\hline 11 Career Inf. Gathering & $\begin{array}{l}\text { 'I regularly collect information about } \\
\text { career opportunities.' }\end{array}$ & 3 & $2.68(1.15)$ & .91 & .31 & .73 & .21 & .03 & .17 & .28 & .08 & .04 & .08 & .42 & \\
\hline 12 Continuous Learning & $\begin{array}{l}\text { 'I continuously develop my work- } \\
\text { related abilities.' }\end{array}$ & 3 & $3.48(0.74)$ & .70 & .57 & .46 & .39 & .43 & .50 & .40 & .31 & .42 & .30 & .52 & .39 \\
\hline
\end{tabular}




\section{Data analysis}

All calculations were done in $R$ ( $R$ Core Team, 2020), using the package Lavaan for structural equation modelling (Rosseel, 2012). For the analyses, the CRQ was specified as described in Hirschi et al. (2019) but without the second-order factors. The model had a good fit with $\chi^{2}(599)=1255.223$, $p<.01, \mathrm{CFI}=.93, \mathrm{RMSEA}=.05, p>.41$. A model with strict measurement invariance across groups also fit the data well, with $\chi^{2}(1288)=2079.934, p<.01, \mathrm{CFI}=.915$, RMSEA $=.054$ for voluntary work, $\chi^{2}(1288)=2213.067, p<.01, \mathrm{CFI}=.902, \mathrm{RMSEA}=.058$ for sport, and $\chi^{2}(1288)=2149.983, p<.01, \mathrm{CFI}$ $=.910, \mathrm{RMSEA}=.056$ for first generation. To compare the latent means between the groups, the loadings and the manifest intercepts were restricted to be the same between the groups by setting the latent intercepts of one group to zero. The latent intercepts of the other group can therefore be interpreted as the deviation to the first group. If the specific value is significantly different to zero, this means that the means of both groups are significantly different.

\section{Results}

The differences between the three groups are presented in Table 3.

Table 3: Differences in Latent Means between Groups

\begin{tabular}{llll}
\hline CRQ-Dimension & Volunteers & Sports participants & First Generation \\
\hline Occupational Expertise & 0.22 & 0.23 & 0.21 \\
Job Market Knowledge & 0.14 & 0.15 & 0.15 \\
Soft Skills & $0.24^{*}$ & $0.51^{*}$ & 0.16 \\
Involvement & 0.11 & 0.21 & 0.03 \\
Confidence & $0.24^{*}$ & $0.57^{*}$ & -0.06 \\
Clarity & 0.04 & 0.06 & $0.37^{*}$ \\
Institutional Support & 0.14 & $0.30^{*}$ & 0.07 \\
Study Challenge & 0.10 & 0.16 & 0.03 \\
Social Support & $0.29^{*}$ & $0.46^{*}$ & $-0.25^{*}$ \\
Networking & 0.23 & $0.31^{*}$ & 0.01 \\
Career Information Gathering & 0.05 & 0.10 & $0.26^{*}$ \\
Continuous Learning & 0.21 & $0.39^{*}$ & 0.04 \\
\hline
\end{tabular}

Note: $* \mathrm{p}<0.05$.

\section{Volunteers}

For the groups of volunteers and non-volunteers significant differences were found in the latent means for the predictors soft skills, confidence and social support. In these areas the volunteers scored higher than the group of non-volunteers. Accordingly, these findings are in line with our hypotheses concerning soft skills and confidence. Conversely, this study does not support the hypotheses around occupational expertise, clarity, and networking.

\section{Sports participants}

For the groups of sports participants and non-sports participants, significant differences were found in the latent means for the predictors soft skills, confidence, institutional support, social support, 
networking and continuous learning. In these areas the group of sports participants scored higher than the group of non-sports participants. Accordingly, the original hypotheses regarding soft skills and confidence are supported. Conversely, the survey results do not support the hypotheses around involvement (where a negative correlation may have been expected), and clarity. In addition, the survey demonstrates a positive correlation for institutional support and social support, whereas it was assumed there may have been no difference in these areas between the two groups.

\section{First generation}

For the groups of first-generation students and the continuing-generation students, significant differences were found in the latent means for the predictors clarity, social support, and career information gathering. In the areas of clarity and career information gathering the group of firstgeneration students scored higher than the group of continuing-generation students. However, for the area of social support the group of the first-generation students scored lower than the group of continuing-generation students. Accordingly, the hypothesis regarding social support is in agreement with these results. Conversely, the hypotheses around involvement, institutional support and networking are not supported, whereas differences were found for clarity and career information gathering, where it was expected that there may have been no difference between the two groups.

\section{Discussion}

Employability is an important aspect in Higher Education and the research demonstrates that individual prerequisites and the personal development of career resources are related. This paper has focused on a closer examination of some of these individual influencing factors. In doing so, the authors have turned their attention to those factors that affect a particularly large number of students and from which insights for career counselling and seminars in career education can be derived. The study was able to show that the strength of individual career resources does indeed vary in the light of individual differences in experiential backgrounds. In particular, the results of existing research could be confirmed that students who are active in voluntary work and sports show higher levels of soft skills and confidence (Allen et al., 2013; Barton et al., 2017; Bourner \& Millican, 2011; Jackson, 2012; Perry, 2014) than students who are not involved in these areas. These findings suggests that extra-curricular activities, even if they are in very different fields, in fact offer opportunities for the development of soft skills and confidence. In addition, this study shows a connection between volunteer engagement and sports activities from one perspective and the strength of the perceived social support from another perspective. The hypothesis that extracurricular activities may impair academic involvement (Dwyer \& Gellock, 2018; Hustinx et al., 2005) was not supported. Taken together, these results suggest that there is a positive effect of external student involvement on career resources.

With regard to first-generation students, it was particularly interesting that the hypothesis that their perceived institutional support might be weaker than that of continuing-generation students was not confirmed. Also not confirmed was the hypothesis that the professionally relevant network of FGS may be weaker than that of CGS. At the same time, however, FGS were found to be more pronounced in terms of professional clarity and career information gathering than the continuousgeneration students. These results call for caution in viewing first-generation students too strongly from a deficit-oriented perspective, even if this study confirmed the presumed weaker social support (Jenkins et al., 2013). The following sections explore the results for the three groups in more detail.

\section{Volunteers}

The fact that volunteers outperform non-volunteers regarding soft skills, confidence, and social support appears plausible. In their volunteer work, students are exposed to a number of new

Eimer, A., \& Bohndick, C. (2021). How individual experiential backgrounds are related to the development of employability among university students. Journal of Teaching and Learning for Graduate Employability, 12(2), 114-130. 
situations and challenges. This fact makes it very likely for these students to develop new skills. Helping others will create positive feedback and this then strengthens confidence. In addition, working together for common goals and based on shared values connects the individuals involved and can lead to supporting each other even in areas beyond the shared tasks. Interestingly, in this survey volunteers score higher in three out of four categories of the Career Resources Model (Hirschi et al., 2019; Hirschi et al., 2018) applied here: knowledge and skills, motivation, and environment. This is a broad basis for potentially setting resources gain spirals in motion (Halbesleben et al., 2014). This means that even career resources that were not primarily changed by the activity could be strengthened.

Despite some references in the scientific literature, the hypotheses presented here on occupational expertise, clarity and networking (Rothwell \& Charleston, 2013) were not confirmed. Regarding occupational expertise, the phenomenon of perceived employability (Jackson \& Wilton, 2017) might interfere: Students can have a quite narrow view of their expertise and regard only those fields that are closely linked to their study programs as relevant to their future working life. Knowledge and skills acquired elsewhere are often not perceived as professionally relevant which can be the case for experience from voluntary work, too. The fact that in their self-assessment volunteers did not score higher than non-volunteers in clarity and networking could indicate that students see their volunteer work as disconnected from their fields of study. Therefore, they might not see this activity as helpful to clarify job perspectives or to reach out to potential employers.

\section{Sports participants}

The sports participants scored higher than the participants not doing sports in the career resources soft skills and confidence, which is in line with the respective hypotheses. Sportspersons can strengthen their soft skills such as cooperation, conflict resolution and communication skills for example through team sports. It may be suggested that this effect is increased when the sports participants additionally engage in managerial tasks in their clubs. Productive handling of defeats, but also self-affirmation through sporting success and good results in competition are likely to contribute here. On the other hand, assumptions that sports participants would score higher on clarity than the comparison group were not supported. If it was assumed that the group of sports participants is also characterised by special mental toughness (Perry, 2014), this quality does not transform into clarity around career goals in this study. This may show that students require more than just determination to be clear about their career goals, also needing specific information and targeted guidance.

While it might be assumed that being active in sport might also correlate with a lower involvement in Higher Education or with poorer academic performance, this was not confirmed. Some research points to this, particularly in connection with increased alcohol consumption among students who do sport (Martha et al., 2009; Partington et al., 2010). Presumably, this is more a socio-cultural behaviour in some countries, but is less common at German universities.

\section{First generation}

The group of first-generation students reported weaker social support than the group of continuinggeneration students. This result is consistent with previous research. Lack of academic support from family and friends, and possibly different values between first-generation students and their private environment may lead to this individual impression. Mostly seen by researchers as a deficit, Tate et al. (2015) found that this lack of social support might turn into a strength: It might motivate firstgeneration students to be successful on their own, becoming a role model for siblings. In this context, the positive correlation between being an FGS and career information gathering can be seen: When these students perceive their social support as relatively weak and feel a stronger individual responsibility, it seems plausible that they look for external sources of information about 
potential career perspectives that they cannot get in their private environment. Similarly, their greater clarity could be explained: Having no family role model but being motivated to succeed in Higher Education it is comprehensible that they more intensively try to clarify their individual perspective than CGS with their supporting background and network.

Furthermore, it was assumed that for FGS the opportunity of an academic education was significant, which is why a stronger involvement for FGS was hypothesised. This hypothesis, however, was not supported by the results of this study. In the Career Resources Questionnaire (Hirschi, 2012; Hirschi et al., 2019) the resource of involvement is defined as an emotional connectedness with the Higher Education sphere. In this emotional aspect, we might find the explanation that FGS - although working in a disciplined, 'involved' way on their study success - might nevertheless feel emotionally unaffiliated with the university and thus less involved. In one study, weak involvement in the sense of low level 'campus connectedness' moderated higher levels of barriers to be associated with more negative career outcome expectations (Ma \& Shea, 2019).

Finally, our assumptions that FGS would score lower in their self-assessment of institutional support and in networking than CGS were not supported. Based on previous research (Raque-Bogdan \& Lucas, 2016) it was assumed that FGS are less likely to accept institutional support because of their strong sense of individual responsibility for their study success. In this sample, the students did not hesitate to make use of career support offered by their university. In addition, they rated their networks just as strong as CGS.

\section{Practical implications}

With rising student numbers in many regions of the world, it is important for Higher Education to address the issue of heterogeneity. Students are increasingly diverse - and this applies not only to their preconditions for their study programs, but also to the different experiences, which ultimately affect their employability. This means that teaching and promoting employability at universities should also take account of individual differences. Career counsellors for example need to take into account the individual differences that they become aware of through their guidance sessions. It is important for them to point out aspects to students that are strong elements in their future professional profiles. This could also help promote students' perceived employability. Often students are not fully aware of which experiences, knowledge and attitudes are relevant and helpful in their future careers.

Overall, from the results of this study it can be concluded that volunteer work correlates positively with the degree of employability. This could lead to the view that volunteer work should be integrated into the curriculum. However, a cautious approach is advisable here: The external framework could demotivate students who are intrinsically motivated to engage in voluntary work. We know this phenomenon as the over-justification effect, when intrinsic motivation and external rewards interfere (Rothwell \& Charleston, 2013). However, motivated students should be encouraged to engage in voluntary work and everyday study should allow time for this (Greenbank, 2014). In addition, those students, who wish to be supported in this engagement e.g. by Professional Development Planning (PDP) or opportunities to reflect on their experience, should get appropriate offers of support by their HE institutions (Barton et al., 2017). It is well-known that young people from wealthier families are more likely to volunteer than those from socially weaker families (The National Council for Voluntary Organisations [NCVO], 2019). They may also have access to stronger social networks when looking for volunteering opportunities. It would be worthwhile for counsellors and other university representatives to think about measures that also give underprivileged groups better opportunities to engage in volunteering, so that students from these groups can also benefit from its positive effects on their employability. 
Initial evidence suggests that students often find it difficult to see what positive qualities relevant for employment are developed through sport (Greenbank, 2014). This is where counsellors can raise awareness amongst their students and encourage their focus precisely on this growth in competence through sport. This can contribute to their perceived employability.

In brief, as a result of this study it is recommended that students be encouraged and supported to engage in voluntary work and to gain beneficial experiences in sport rather than making these activities compulsory.

When counsellors work with first-generation students, one aim might be to build up additional strengths that are (individually and initially) lacking. On the other hand, counsellors should also be aware of the particular strengths that many first-generation students already possess, such as their goal orientation and their self-responsibility. In any case, various studies including this one highlight that it is prejudiced to regard first-generation students primarily through a deficit-oriented lens. In addition, career counsellors, who have been first-generation students themselves, are well placed to support their students by self-disclosing this aspect of their own biography (Krieger Cohen \& Johnson, 2020). In this way, career counsellors can mitigate first-generation students' feelings of isolation and of insecurity regarding their future careers and above that strengthen FGS' emotional connectedness with their institution and $\mathrm{HE}$ in general.

Whilst it is not always possible to specifically address individual differences in group sessions in comparison with 1:1 counselling, nevertheless the topic of heterogeneity can be approached and discussed in group settings. One simple way to do this in practice is to invite the participants to share their diverse backgrounds. This can lead to diversity also becoming visible in terms of professional development and making it easier for participants to discuss their own biographies in an appreciative and supportive environment. Thus, they can see the value of their individual development in a way that is detached from external expectations and values.

This study focuses on individual preconditions for the development of employability, however as mentioned previously in this paper socio-economic aspects must also not be forgotten. Career education professionals, whether they are conducting individual counselling or offering workshops, should ensure that students are fully aware that they are not the only consideration in terms of future success of their careers. The labour market situation, the economic and social situation, geographical factors or political developments, for example, are all factors which generally are beyond the direct control of the individual (Moreau \& Leathwood, 2006). Discussing these facts with students, and clarifying what the sphere of personal influence is can also reduce insecurity and help to ultimately strengthen employability.

\section{Limitations and need for further research}

This paper presents some insights into the correlation between individual prerequisites for learning and the development of employability. However, some limitations need to also be acknowledged. The sample comes from only one university in Germany. As mentioned the beginning of the paper, employability is an internationally relevant aspect in Higher Education with nationally specific points of view. Therefore, the relevance of individual preconditions for the development of career resources could be examined in other countries and from other cultural backgrounds, too.

The results presented here are from a cross-sectional study. It would be important to investigate how the influence of factors applied in this study potentially develop over a longer period of time and what influence the differences of individual sub-groups have from a longitudinal perspective.

As mentioned previously, there is evidence (Hu et al., 2020; Lehmann, 2019; Raque-Bogdan \& Lucas, 2016) that the socio-economic status is an important influencing factor on employability and career aspirations for both, first-generation and continuing-generation students. This aspect needs further 
consideration for university students from a variety of different perspectives if these inequalities are to be better addressed in the future.

Furthermore, the influence of sport on employability could be investigated in a more differentiated way. For high-school students, a correlation between participation specifically in team sports and improved grades could be established (Allen et al., 2013). Further questions could also be interesting to test in relation to university students, e.g. effects of team sport on networking and social capital.

Finally, in this study, interactional aspects between FGS, volunteering and sports participation with other influencing variables such as age, field of study, stage of study, ethnicity, etc. were not explored. This intersectionality could also be taken into account in future research.

\section{References}

Abele-Brehm, A. E., \& Spurk, D. (2009). The longitudinal impact of self-efficacy and career goals on objective and subjective career success. Journal of Vocational Behavior, 74(1), 53-62. https://doi.org/10.1016/j.jvb.2008.10.005

Allen, K., Bullough, S., Cole, D., Shibili, S., \& Wilson, J. (2013). The impact of engagement in sport on graduate employability. Final report. Sheffield. Retrieved from http://hdl.voced.edu.au/10707/260938

Astin, A. W., Say, L. J., \& Avalos, J. (1999). Long-term effects of volunteerism during the undergraduate years. The Review of Higher Education, 22(2), 187-202. Retrieved from http://digitalcommons.unomaha.edu/slcehighered/88

Barton, E., Bates, E. A., \& O’Donovan, R. (2017). 'That extra sparkle': Students' experiences of volunteering and the impact on satisfaction and employability in higher education. Journal of Further and Higher Education, 43(4), 453-466. https://doi.org/10.1080/0309877X.2017.1365827

Bourner, T., \& Millican, J. (2011). Student-community engagement and graduate employability. Widening Participation and Lifelong Learning, 13(2), 68-85. https://doi.org/10.5456/WPLL.13.2.68

Brunton, J. (2017). Interpreting university sport policy in England: Seeking a purpose in turbulent times? International Journal of Sport Policy and Politics, 9(3), 377-395. https://doi.org/10.1080/19406940.2017.1359201

Coakley, J. (2015). Assessing the sociology of sport: On cultural sensibilities and the great sport myth. International Review for the Sociology of Sport, 50(4-5), 402-406. https://doi.org/10.1177/1012690214538864

The Council of the European Union (2014). Resolution of the Council and of the representatives of the governments of the member states, meeting within the Council, of 21 May 2014 on the European Union work plan for sport (2014-2017). Official Journal of the European Union, 183(03), 12-16. Retrieved from https://eur-lex.europa.eu/legal-content/EN/TXT/PDF/?uri=CELEX:42014Y0614(03)\&from=EN

Department for Business Innovation \& Skills (2016). Success as a knowledge economy: Teaching excellence, social mobility and student choice. Retrieved from https://assets.publishing.service.gov.uk/government/uploads/system/uploads/attachment data/file/5233 96/bis-16-265-success-as-a-knowledge-economy.pdf

Department for Digital, Culture, Media and Sport (2020). Share of adults who volunteered in the last 12 months in England from 2015/16 to 2019/20, by age. Retrieved from https://www.statista.com/statistics/420100/volunteers-uk-england-by-age/

Dwyer, B., \& Gellock, J. L. (2018). Does athletic participation signal employability? An experimental analysis of male and female athlete job applicants. Journal of Intercollegiate Sport, 11(1), 40-64. https://doi.org/10.1123/iis.2017-0037

Eimer, A., Knauer, J., Kremer, I., Nowak, T., \& Schröder, A. (2019). Employability als ein Ziel des Universitätsstudiums: Grundlagen, Methoden, Wirkungsanalyse (1. Auflage). Bielefeld: wbv.

Gervais, S. (2014). A study comparing motivation and self-efficacy of first generation students and non-first generation students in their first year of post- secondary studies (Dissertation, The University of Alabama). Retrieved from https://ir.ua.edu/handle/123456789/2177

Gibbons, M. M., \& Borders, L. D. (2010). Prospective first-generation college students: A social-cognitive perspective. The Career Development Quarterly, 58(3), 194-208. https://doi.org/10.1002/j.2161$\underline{0045.2010 . t b 00186 . x}$ 
Goodman, S., \& Tredway, G. (2016). Antecedents of perceived graduate employability: A study of student volunteers in a community-based organisation. SA Journal of Industrial Psychology, 42(1), a1315. https://doi.org/10.4102/sajip.v42i1.1315

Greenbank, P. (2014). Competing in the graduate labour market: Student perspectives on (not) participating in extra-curricular activities. Journal of Teaching and Learning for Graduate Employability, 5(1), 63-79. https://doi.org/10.21153/itlge2014vol5no1art568

Halbesleben, J. R. B., Neveu, J.-P., Paustian-Underdahl, S. C., \& Westman, M. (2014). Getting to the "COR": Understanding the role of resources in conservation of resources theory. Journal of Management, 40(5), 1334-1364. https://doi.org/10.1177/0149206314527130

Hinchliffe, G. W., \& Jolly, A. (2011). Graduate identity and employability. British Educational Research Journal, 37(4), 563-584. https://doi.org/10.1080/01411926.2010.482200

Hirschi, A. (2012). The career resources model: An integrative framework for career counsellors. British Journal of Guidance \& Counselling, 40(4), 369-383. https://doi.org/10.1080/03069885.2012.700506

Hirschi, A., Hänggli, M., Nagy, N., Baumeler, F., Johnston, C., \& Spurk, D. (2019). Karriere-Ressourcen messen. Diagnostica, 65(3), 133-141. https://doi.org/10.1026/0012-1924/a000219

Hirschi, A., Nagy, N., Baumeler, F., Johnston, C. S., \& Spurk, D. (2018). Assessing key predictors of career success. Journal of Career Assessment, 26(2), 338-358. https://doi.org/10.1177/1069072717695584

HM Government (2015). Sporting future: A new strategy for an active nation. London. Retrieved from https://assets.publishing.service.gov.uk/government/uploads/system/uploads/attachment data/file/4866 22/Sporting Future ACCESSIBLE.pdf

Hu, S., Hood, M., Creed, P. A., \& Shen, X. (2020). The relationship between family socioeconomic status and career outcomes: A life history perspective. Journal of Career Development, 82. https://doi.org/10.1177/0894845320958076

Hustinx, L., Vanhove, T., Declercq, A., Hermans, K., \& Lammertyn, F. (2005). Bifurcated commitment, priorities, and social contagion: The dynamics and correlates of volunteering within a university student population. British Journal of Sociology of Education, 26(4), 523-538. https://doi.org/10.1080/01425690500200111

International Education Association Australia (2019, December 1). Short-term international study enhances employability. Retrieved from https://www.ieaa.org.au/news/short-term-international-study-enhancesemployability

Jackson, D. (2012). Testing a model of undergraduate competence in employability skills and its implications for stakeholders. Journal of Education and Work, 27(2), 220-242. https://doi.org/10.1080/13639080.2012.718750

Jackson, D., \& Wilton, N. (2017). Perceived employability among undergraduates and the importance of career self-management, work experience and individual characteristics. Higher Education Research \& Development, 36(4), 747-762. https://doi.org/10.1080/07294360.2016.1229270

Jenkins, S. R., Belanger, A., Connally, M. L., Boals, A., \& Durón, K. M. (2013). First-generation undergraduate students' social support, depression, and life satisfaction. Journal of College Counseling, 16(2), 129-142. https://doi.org/10.1002/i.2161-1882.2013.00032.x

Kammeyer-Mueller, J. D., Judge, T. A., \& Piccolo, R. F. (2008). Self-esteem and extrinsic career success: Test of a dynamic model. Applied Psychology, 57(2), 204-224. https://doi.org/10.1111/j.1464-0597.2007.00300.x

Knutson, N. M. (2011). Applying the Rasch model to measure and compare first-generation and continuinggeneration college students' academic self-efficacy (Dissertation, University of Kentucky). Retrieved from https://uknowledge.uky.edu/cgi/viewcontent.cgi?article=1000\&context=epe etds

Krieger Cohen, P. E., \& Johnson, A. T. (2020). Career counselors self-disclosing to first-generation college students: A grounded theory study. Journal of Career Development, 46(6). https://doi.org/10.1177/0894845320941251

Lehmann, W. (2019). Forms of capital in working-class students' transition from University to employment. Journal of Education and Work, 32(4), 347-359. https://doi.org/10.1080/13639080.2019.1617841

Ma, P.-W. W., \& Shea, M. (2019). First-generation college students' perceived barriers and career outcome expectations: Exploring contextual and cognitive factors. Journal of Career Development, 48(2), 91-104. https://doi.org/10.1177/0894845319827650

Manzoni, A., \& Streib, J. (2019). The equalizing power of a college degree for first-generation college students: Disparities across institutions, majors, and achievement levels. Research in Higher Education, 60(5), 577605. https://doi.org/10.1007/s11162-018-9523-1 
Martha, C., Grélot, L., \& Peretti-Watel, P. (2009). Participants' sports characteristics related to heavy episodic drinking among French students. The International Journal on Drug Policy, 20(2), 152-160.

https://doi.org/10.1016/i.drugpo.2007.11.023

Millard, L. (2020). Students as colleagues: The impact of working on campus on students and their attitudes towards the university experience. The Journal of Teaching and Learning for Graduate Employability, 11(1), 37-49.

Moreau, M.-P., \& Leathwood, C. (2006). Graduates' employment and the discourse of employability: A critical analysis. Journal of Education and Work, 19(4), 305-324. https://doi.org/10.1080/13639080600867083

Muldoon, R. (2009). Recognizing the enhancement of graduate attributes and employability through part-time work while at university. Active Learning in Higher Education, 10(3), 237-252. https://doi.org/10.1177/1469787409343189

Murata, A. (2014). Designing youth employment policies in Egypt (working paper 68). Retrieved from https://www.brookings.edu/wp-content/uploads/2016/06/Arab-EconPaper3Murata-v5.pdf

The National Council for Voluntary Organisations (2019). UK civil society almanac 2020 DATA. TRENDS. INSIGHTS. Retrieved from https://data.ncvo.org.uk/volunteering/demographics/

Ng, T. W. H., Eby, L. T., Sorensen, K. L., \& Feldman, D. C. (2005). Predictors of objective and subjective career success: A meta-analysis. Personnel Psychology, 58(2), 367-408. https://doi.org/10.1111/i.1744$\underline{6570.2005 .00515 . x}$

NUSNews (2016, November 17). NUS graduates are $15^{\text {th }}$ most employable in the world. Retrieved from https://news.nus.edu.sg/nus-graduates-are-15th-most-employable-in-the-world/

OECD (Ed.) (2017). Report on benchmarking Higher Education system performance: Conceptual framework and data: Enhancing Higher Education system performance [Special issue]. Paris. Retrieved from www.oecd.org

Partington, S., Partington, E.,Heather, N., Gibson, A., Longstaff, F., Allsop, S.;, Warenham, H., \& Jankowski, M. (2010). Use and abuse of alcohol in UK university sport. Newcastle- upon-Tyne: Northumbria University. Retrieved from https://s3.eu-west-

2.amazonaws.com/files.alcoholchange.org.uk/documents/AERC FinalReport 0074.pdf?mtime=201811170 $\underline{93657}$

Perry, J. L. (2014). Sport and its role in developing young people. In D. Strycharczyk \& P. Clough (Eds.), Developing mental toughness in young people: Approaches to achievement, well-being, employability and positive behaviour (pp. 181-189). London: Karnac Books.

$\mathrm{R}$ Core Team (2020). R: A language and environment for statistical computing. R Foundation for Statistical Computing. Vienna. http://www.r-project.org/index.html

Raque-Bogdan, T. L., \& Lucas, M. S. (2016). Career aspirations and the first generation student: Unraveling the layers with social cognitive career theory. Journal of College Student Development, 57(3), 248-262. https://doi.org/10.1353/csd.2016.0026

Rosseel, Y. (2012). Lavaan. An r package for structural equation modeling. Journal of Statistical Software, 48(2), $1-36$.

Rothwell, A., \& Charleston, B. (2013). International volunteering: employability, leadership and more. Education and Training, 55(2), 159-173. https://doi.org/10.1108/00400911311304805

RTI International (2019). First-generation college students: Demographic characteristics and postsecondary enrollment. Washington, DC.

Souto-Otero, M., Ulicna, D., Schaepkens, L., \& Bognar, V. (2012). Study on the impact of non-formal education in youth organisations on young people's employability. Bath, UK: European Youth Forum. https://researchportal.bath.ac.uk/en/publications/study-on-the-impact-of-non-formal-education-in-youthorganisation

Sutin, A. R., Costa, P. T., Miech, R., \& Eaton, W. W. (2009). Personality and career success: Concurrent and longitudinal relations. European Journal of Personality, 23(2), 71-84. https://doi.org/10.1002/per.704.

Tate, K. A., Caperton, W., Kaiser, D., Pruitt, N. T., White, H., \& Hall, E. (2015). An exploration of first-generation college students' career development beliefs and experiences. Journal of Career Development, 42(4), 294310. https://doi.org/10.1177/0894845314565025

UNESCO International Institute for Education Planning (2017). Six ways to ensure Higher Education leaves no one behind. Retrieved from https://euagenda.eu/upload/publications/untitled-87075-ea.pdf

Wolff, H.-G., \& Moser, K. (2009). Effects of networking on career success: A longitudinal study. The Journal of Applied Psychology, 94(1), 196-206. https://doi.org/10.1037/a0013350 
You, J. W. (2020). The relationship between participation in extracurricular activities, interaction, satisfaction with academic major, and career motivation. Journal of Career Development, 47(4), 454-468.

https://doi.org/10.1177/0894845318802108 